\title{
Pathophysiology of hypercalciuria in children
}

\author{
Tarak Srivastava $\cdot$ Uri S. Alon
}

Received: 3 February 2007 / Revised: 11 March 2007 / Accepted: 12 March 2007 / Published online: 27 April 2007

(C) IPNA 2007

\begin{abstract}
Urinary excretion of calcium is the result of a complex interplay between three organs-namely, the gastrointestinal tract, bone, and kidney - which is finely orchestrated by multiple hormones. Hypercalciuria is believed to be a polygenic trait and is influenced significantly by diet. This paper briefly reviews calcium handling by the renal tubule in normal and in hereditary disorders as it relates to the pathophysiology of hypercalciuria. The effects of dietary sodium, potassium, protein, calcium, and phosphate on calcium excretion, and the association of hypercalciuria with bone homeostasis is discussed, leading to recommendations on means to address excessive urinary calcium excretion.
\end{abstract}

\section{Keywords Hypercalciuria · Children}

\section{Introduction}

Albright et al. [1] first introduced the term idiopathic hypercalciuria to describe patients with recurrent urolithiasis who had elevated urinary calcium excretion without concomitant hypercalcemia. The etiology of hypercalciuria is complex given that urinary excretion of calcium is the end result of an interplay between three organs-namely, the gastrointestinal tract, bone, and kidney-which is further orchestrated by hormones, such as 1,25-dihydroxyvitamin $\mathrm{D}_{3}\left(1,25-(\mathrm{OH})_{2} \mathrm{D}_{3}\right)$, parathyroid hormone $(\mathrm{PTH})$,

T. Srivastava $\cdot$ U. S. Alon $(\square)$

Section of Nephrology, Bone and Mineral Disorder Clinic,

The Children's Mercy Hospital and Clinics,

University of Missouri,

2401 Gillham Road,

Kansas City, MO 64108, USA

e-mail: ualon@cmh.edu calcitonin, fibroblast growth factor (FGF-23), etc. Often, a primary defect in one organ induces compensatory mechanisms in the remaining two organs, such as increased absorption of calcium in the gut secondary to a primary renal loss. Hypercalciuria can be either idiopathic or secondary. In this review, idiopathic hypercalciuria and the recent developments in hereditary renal tubular disorders associated with hypercalciuria is discussed, providing an insight into the pathophysiology of hypercalciuria. The role of diet in hypercalciuria and the clinical relationship of hypercalciuria with urolithiasis and bone mineral density (BMD) is also discussed.

\section{Genetics of hypercalciuria}

Hypercalciuria is the most common metabolic abnormality detected in children with stones, causing mostly the formation of calcium oxalate stones and to a lesser extent calcium phosphate stones or a mixture of the two [2-4]. The reported incidence for urolithiasis in Icelandic children is $6.3 / 100,000$ children $<16$ years of age [2]. In adults, Curhan et al. [5] reported 14-27\% hypercalciuria in a cohort of control population identified from the three large studies: Nurses' Health Study I (NHS I), NHS II, and Health Professional Follow-up Study, whereas it was 25$38 \%$ in stone formers in the same cohort. Coe et al. [6] assessed that $5 \%$ of American women and $12 \%$ of men will develop a kidney stone at some time in their life. A positive family history appears to be the single most important risk factor after controlling for known dietary factors [7]. In children with hypercalciuria, the prevalence of urolithiasis in the family is $69 \%$ [8]. Reed et al. [9] mapped a defect in three families with severe absorptive hypercalciuria to 1q23.3-q24, and they subsequently sequenced a putative 
gene (homologous to rat soluble adenylate cyclase gene). They identified 18 base substitutions in the putative gene, four of which increased the relative risk of absorptive hypercalciuria by $2.2-$ to 3.5 -fold [10]. Vezzoli et al. [11] found single nucleotide polymorphism Arg990Gly in the calcium-sensing receptor (CASR) gene to account for $4.1 \%$ of total variance in calcium excretion and $12.6 \%$ of total variance in calcium excretion if independent variables of sodium excretion, body weight, serum creatinine, and enteral absorption of strontium were added to the multiple regression model. Imamura et al. [12] and Giuffre et al. [13] described three unrelated children with hypercalciuria who have 4q33-qter and 4q31.3-qter deletion, respectively, which raises the potential for a putative gene for hypercalciuria in that region. At this point, hypercalciuric trait is suspected to be polygenic and requires the interaction of genetic and/or environmental factors [14, 15]. A familial clustering of idiopathic calcium nephrolithiasis is frequently observed, most often compatible with an autosomal dominant transmission, but the quantitative genetics of urine calcium excretion has not been established. LoredoOsti et al. [16] believe that either a mixed codominant/ polygenic model or a single-gene codominant model best determines the estimated inheritable attribute for idiopathic hypercalciuria, and thus it should be feasible to genetically map the quantitative trait locus for idiopathic hypercalciuria.

\section{Physiology of calcium absorption and its implication in diseases}

Calcium exists in three distinct pools in the body, where it is tightly regulated. The largest pool is that in the skeleton in the molar range, followed by the extracellular calcium pool in the millimolar range, and the third is in the intracellular space, which contains no more than $1 \mu \mathrm{m}$ of calcium in an adult.

\section{Calcium absorption in the gastrointestinal tract}

Calcium absorption in the gastrointestinal tract is a sum of two transport processes: a saturable transcellular absorption that is physiologically regulated by vitamin $\mathrm{D}$, and a nonsaturable paracellular absorption that is dependent on the calcium concentration within the lumen, which in turn depends on dietary calcium load. The nonsaturable paracellular pathway is thought to predominate when the diet is replete in calcium, whereas the saturable vitamin-Ddependent transcellular pathway becomes critical when the dietary calcium is limited.

The active transcellular absorption is mediated by epithelial transient receptor potential (TRP) calcium chan- nels TRPV5 (epithelial calcium channel: $\mathrm{ECaCl}$ ) and TRPV6 (CaT1 or $\mathrm{ECaC} 2)$, which are under the regulation of 1,25-(OH $)_{2} \mathrm{D}_{3}[17,18]$. TRPV5 and TRPV6 calcium channels are transmembrane proteins that belong to the superfamily of TRP channels. TRPV5 and TRPV6 have been mapped to chromosomes 7q35 and 7q33-34, respectively, and are believed to be products of evolutionary local gene duplication $[19,20]$. TRPV5 and TRPV6 are coexpressed in the intestine and kidney; however, TRPV6 is more abundant and is believed to be the major calcium channel in the intestine [21-23]. TRPV6 is expressed from the esophagus down to the jejunum, whereas TRPV5 is restricted to the duodenum and jejunum. In contrast, TRPV5 is abundantly expressed in the renal distal convoluted duct and connecting tubule, whereas limited expression of TRPV6 is observed in the distal convoluted tubule (DCT), connecting tubule, and collecting duct [22, 23]. In the intestine, TRPV6 is present in a thin layer along the apical membrane of the duodenal villus tip and colocalizes with calbindin-D $(9 \mathrm{~K})$ and plasma membrane $\mathrm{Ca}(2+)$-ATPase (PMCA), all involved in calcium transport.

\section{Calcium absorption in the kidney}

Only filterable calcium, i.e., non-albumin-bound calcium, is filtered in the glomerulus to the urinary space. The calcium in the glomerular ultrafiltrate is then handled throughout the renal tubule to maintain calcium homeostasis. The retrieval of $\sim 70 \%$ calcium occurs in the proximal tubule and $\sim 20 \%$ in the thick ascending loop of Henle (TALH), predominantly by a paracellular mechanism. The calcium absorption in the proximal tubule occurs mainly from the solvent drag that occurs from salt and water absorption, whereas in the TALH, the paracellular calcium absorption is driven by the lumen-positive potential generated by the sodium absorption from the $\mathrm{Na}^{+}-\mathrm{K}^{+}-2 \mathrm{Cl}^{-}$cotransporter (NKCC2), renal outer-medullary potassium channel (ROMK), and chloride channel (Figs. 1 and 2) [24]. Thus, calcium absorption in the renal tubule is at the mercy of sodium absorption, which is crucially important in the dietary management of hypercalciuria.

The fine tuning of the remaining $\sim 10 \%$ calcium occurs in the DCT, connecting tubule, and initial portion of the cortical collecting duct through an active transcellular pathway (Fig. 3) [25-27]. The molecular nature of the apical epithelial calcium channel TRPV5 was first elucidated by expression cloning and using primary cultures of rabbit connecting tubule [17]. TRPV5 has been identified immunohistochemically in DCT and connecting tubule [22, 23]. TRPV5 colocalizes with calbindin- $\mathrm{D}(28 \mathrm{~K}), \mathrm{Na}(+)-\mathrm{Ca}$ $(2+)$ exchanger (NCX), and PMCA. Calbindin- $\mathrm{D}(28 \mathrm{~K})$ acts as the principal calcium shuttle from the apical to the basolateral surface $[22,23,26]$. The subsequent basolateral 
Fig. 1 Schematic representation of molecular (or transport) mechanisms in the proximal tubule related to Dent's disease and hereditary hypophosphatemic rickets with hypercalciuria. - low molecular weight proteins; NHE-3 $\mathrm{Na}^{+}-\mathrm{H}^{+}$exchanger; I, IIa, IIc, and III Na/Pi type I, type IIa, type IIc and type III cotransporters; $N B C-1 \mathrm{Na}^{+}$$\mathrm{HCO}_{3}^{-}$cotransporter; $C L C-5$ chloride channel-5; $A A$ amino acids; $X^{-}$anion; $P i$ phosphate; $C A$ II cytoplasmic carbonic anhydrase; $C A I V$ membranebound carbonic anhydrase
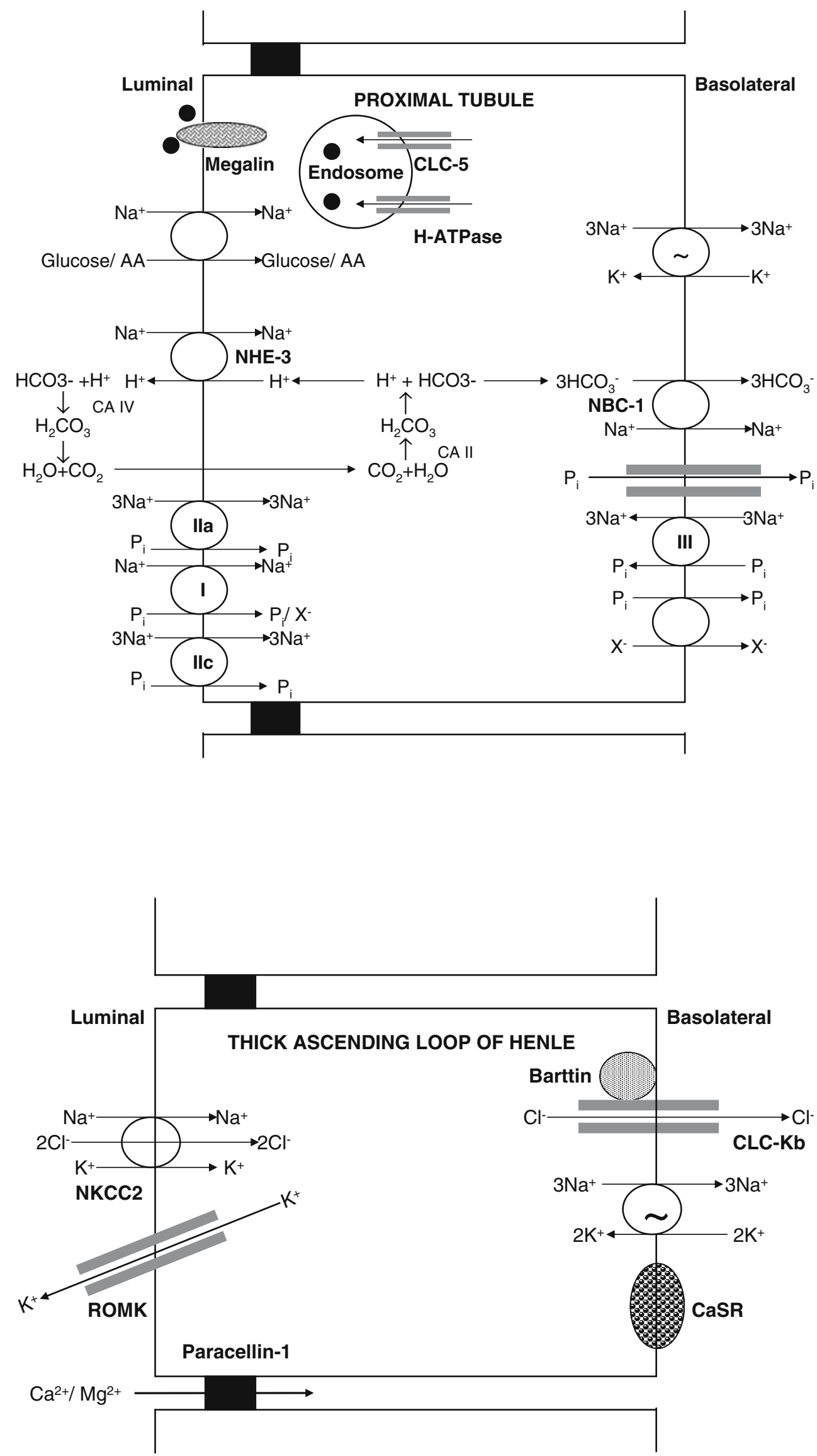

Fig. 2 Schematic representation of molecular (or transport) mechanisms in the thick ascending loop of Henle related to Bartter syndrome and familial hypomagnesemia with hypercalciuria and nephrocalcinosis. $N K C C 2 \mathrm{Na}^{+}-\mathrm{K}^{+}-2 \mathrm{Cl}$ cotransporter, $R O M K$ renal outer-medullary potassium channel, $C L C-K b$ chloride channel $\mathrm{Kb}$, $\mathrm{CaSR}$ calcium-sensing receptor 
Fig. 3 Schematic representation of molecular (or transport) mechanisms in the distal tubule related to pseudohypoaldosteronism (PHA) type II and distal renal tubular acidosis. NCCT $\mathrm{Na}^{+}-\mathrm{Cl}^{-}$cotransporter, TRPV5 calcium channel, $A E 1$ $\mathrm{Cl}^{-}-\mathrm{HCO}_{3}^{-}$exchanger, $\mathrm{CA} I I$ cytoplasmic carbonic anhydrase, $N C X \mathrm{Na}^{+}-\mathrm{Ca}^{2+}$ exchanger, $W N K 1$ with-no-lysine kinase 1 , WNK4 with-no-lysine kinase 4

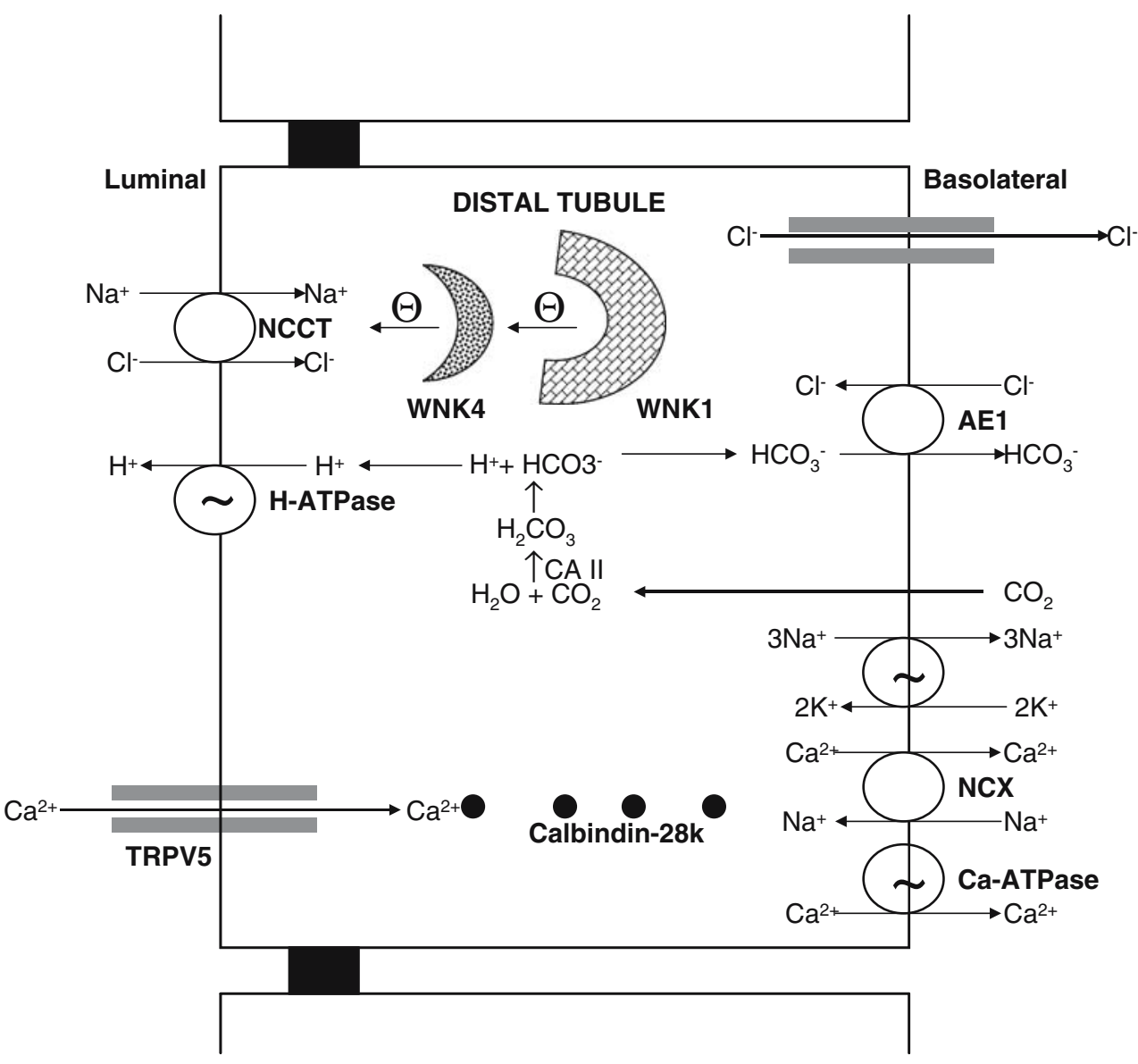

calcium transport occurs via both the plasma membrane NCX and PMCA, which are estimated to transport $70 \%$ and $30 \%$ of calcium, respectively [28, 29]. The calcium transport in the distal tubule is regulated by PTH and 1,25- $(\mathrm{OH})_{2} \mathrm{D}_{3}[28,29]$. Hoenderop et al. [30] demonstrated that mice lacking TRPV5 displayed diminished active calcium absorption despite enhanced vitamin D levels, causing severe hypercalciuria and significant disturbances in bone structure, including reduced trabecular and cortical bone thickness.

\section{Proximal tubule in hypercalciuria}

The majority $(\sim 70 \%)$ of calcium absorption occurs in the proximal tubule in an isosmotic process mainly from the solvent drag that occurs from salt and water absorption [26, 27]. The proximal tubule is critical for bulk absorption of sodium, chloride, phosphate, amino acids, glucose, etc., where the calcium absorption is taking place in an energetically passive mode, and thus a dysfunction as in Fanconi syndrome will result in variable hypercalciuria. Hypercalciuria has been observed in disorders affecting the proximal tubule, such as Lowe syndrome, Wilson's disease, Tyrosinemia type 1, and glycogen storage disease type 1a. Dent's disease and hereditary hypophosphatemic rickets with hypercalciuria where new genetic information has become available will be discussed in more detail.

Dent's disease Dent's disease is now an accepted name for a group of hereditary tubular disorders, including X-linked recessive nephrolithiasis with renal failure, $\mathrm{X}$-linked recessive hypophosphatemic rickets, and idiopathic low-molecularweight proteinuria associated with hypercalciuric nephrocalcinosis resulting from mutations in the CLCN5 gene located on Xp11.22 encoding for the chloride channel 5 (CLC-5) $[31,32]$. CLC-5 belongs to a family of nine known voltagegated, transmembrane-spanning, chloride channel genes. It is localized to endosomes and is expressed in the proximal tubule, TALH, and collecting duct [33, 34]. CLC-5 colocalizes with $\mathrm{H}^{+}$-ATPase, and this pairing is important for acidification of endocytotic vesicles [33]. The degradation activity within the endosome in the proximal tubule is critically dependent on the acidification of the endosomal lumen, which is believed to be mediated by CLC-5. The exact mechanism that underlies hypercalciuria in Dent's disease is still under investigation. CLC-5 defect leads to abnormal regulation of PTH and vitamin D metabolites from diminished recycling of low-molecular-weight proteins, such as luminal PTH receptors, vitamin-D-binding protein, etc. [35-37]. Recent work by Silva et al. [38] demonstrated that 
the hypercalciuria in the CLC-5 knockout mice on low- and high-calcium diets is of bone and renal origin and is not caused by increased intestinal calcium absorption, despite an elevated serum $1,25-(\mathrm{OH})_{2} \mathrm{D}_{3}$.

The phenotypic expression of Dent's disease is quite wide. The disease is more severe in males and is characterized by hypercalciuria, medullary nephrocalcinosis, nephrolithiasis, low-molecular-weight proteinuria and other tubular dysfunctions, and progressive renal failure. The proximal tubular dysfunction can manifest as glucosuria, aminoaciduria, and phosphaturia [39]. Renal failure occurs in about two thirds of patients with Dent's disease; the renal function generally begins to decline in the adolescent years and reaches end stage by the fourth decade of life. Serum calcium levels are normal or highnormal, PTH is low, and levels of $1,25-(\mathrm{OH})_{2} \mathrm{D}_{3}$ are often elevated [31, 39-41]. Hypercalciuria is a hallmark of Dent's disease and is the major risk factor for stone formation and nephrocalcinosis, as these patients excrete normal quantities of oxalate, citrate, uric acid, and other stone-risk determinants $[39,40]$. Infants and young children a have higher degree of calcium excretion, in the range of $10-12 \mathrm{mg} / \mathrm{kg}$, compared with adults, with $4-6 \mathrm{mg} / \mathrm{kg}$, and the hypercalciuria persist while fasting [31]. The hypercalciuria in Dent's disease is responsive to dietary calcium restriction and thiazide diuretics [42].

Hereditary hypophosphatemic rickets with hypercalciuria (HHRH) Tieder et al. [43] reported a Bedouin tribe with hypercalciuria, hypophosphatemic rickets, and elevated calcitriol levels. Patients with this disease have decreased tubular absorption of phosphate and consequently hypophosphatemia, high serum levels of $1,25-(\mathrm{OH})_{2} \mathrm{D}_{3}$, and enhanced intestinal absorption of calcium, resulting in hypercalciuric nephrocalcinosis and urolithiasis. Three types of sodium-phosphate cotransporter have been found in the renal proximal tubule [type I, type IIa, and type III sodium/phosphate $(\mathrm{Na} / \mathrm{Pi})$ cotransporters] [44]. Type I Na/ Pi cotransporter is present on the brush border membrane and has distinct anion channel properties. It is not regulated under normal physiological conditions and is not believed to be a major determinant of phosphorous reabsorbtion by the proximal tubule. The type $\mathrm{IIa} \mathrm{Na} / \mathrm{Pi}$ cotransporter (NPT2a) is highly expressed in the brush border membrane and has been shown to influence $70-80 \%$ of the $\mathrm{Na} / \mathrm{Pi}$ cotransporter activity at the brush border membrane [45]. NPT2a is believed to be the major determinant of phosphorous reabsorbtion by the proximal tubule and thus of the tubular reabsorption for phosphate per liter glomerular filtration rate $(\mathrm{TP} / \mathrm{GFR})$ value $[45,46]$. Absence of renal NPT2a expression leads to increased renal phosphate loss resulting in hypophosphatemia [45]. The NPT2a is inhibited by PTH and FGF-23 [47-49]. The type IIb Na/Pi cotransporter is expressed in the small intestine and other epithelial cells but not in the kidney. The type IIc Na/Pi cotransporter is expressed in the brush border membrane of the proximal tubule in weaning animals and decreases with age $[50,51]$. The type III Na/Pi cotransporter (Glvr-1 and Ram-1) is expressed at the basolateral aspect of the proximal tubule and is believed to play a housekeeping role in maintaining cellular Pi concentration. Tenenhouse et al. [52] showed that Npt1, Npt2, Glvr-1, and Ram-1 account for approximately $15 \%, 84 \%, 0.5 \%$, and $0.5 \%$, respectively, of total $\mathrm{Na}^{+} / \mathrm{Pi}$ cotransporter mRNA in the mouse kidney. Prie et al. [53] sequenced the NPT2a gene from 20 patients with urolithiasis or bone demineralization associated with idiopathic hypophosphatemia and found two patients with NPT2a mutations, one with a substitution of phenylalanine for arginine 48 (exon 3 ) and the second with a methionine for valine 147 substitution (exon 5); both patients were heterozygous for these mutations. Lapointe et al. [54] found no disease-causing mutation in NPT2a in a cohort of recurrent hypercalciuric stone formers with a TP/GFR of $\leq 0.7 \mathrm{mmol} / 1$. Although NPT2a appeared to be a good candidate gene for HHRH, Jones et al. [55] and van den Huevel et al. [56] found no mutation in the gene for NPT2a. Only recently have SLC34A3 mutations in $\mathrm{Na}^{+} / \mathrm{Pi}$-IIc cotransporter been described in patients with HHRH [57].

\section{Thick ascending loop of Henle in hypercalciuria}

The permeability of calcium is very low in the thin descending and ascending loop of Henle. In TALH, where $\sim 20 \%$ of calcium is absorbed, calcium absorption is passive and driven by the large lumen-positive potential created by sodium absorption [26, 27]. Paracellin-1 in the TALH plays a critical role in control of passive calcium absorption. We discuss briefly the recent developments in Bartter syndrome (and calcium-sensing receptor), and familial hypomagnesemia with hypercalciuria and nephrocalcinosis (FHHNC), which have improved the understanding of calcium homeostasis in this segment of the nephron (Fig. 2).

Bartter syndrome Bartter syndrome is a rare, genetically heterogeneous, renal tubular disorder secondary to defects in the transepithelial sodium chloride transport across TALH. This autosomal recessive syndrome is characterized phenotypically by failure to thrive, hypokalemia, metabolic alkalosis, secondary hyperaldosteronism with normal blood pressure, increased urinary prostaglandins excretion, and hypercalciuria with nephrocalcinosis [58]. A breakdown in sodium absorption in Bartter syndrome leads to poor paracellular absorption of calcium, leading to hypercalciuria. Bartter syndrome can occur from mutation in one of the five genes: (a) Bartter type 1 from mutations in the gene 
encoding for the luminal bumetanide-sensitive NKCC2 (gene SLC12A1, locus 15q15), (b) Bartter type 2 from mutations in the gene encoding for the luminal potassium channel ROMK (KCNJ1, locus 11q24), (c) Bartter type 3 from mutations in the gene encoding for the voltage-gated chloride channel on the basolateral membrane (CLC-Kb; gene CLCNKB, locus 1p36), (d) Bartter type 4 from mutations in the gene encoding for Barttin, a beta subunit required for trafficking of $\mathrm{CLC}-\mathrm{Kb}$ and $\mathrm{CLC}-\mathrm{Ka}$ on the basolateral membrane (Barttin; BSND gene, locus 1p31), and (e) Bartter type 5 from activating mutations in the gene encoding for the calcium-sensing receptor located on the basolateral membrane (CaSR; CASR gene, locus 3q13) [59-64].

The clinical presentation of Bartter syndrome can be "classical", or more severe presenting in the perinatal period. Because of the defect in sodium handling by the TALH, there is a failure in the paracellular absorption of calcium, causing hypercalciuria and kidney-stone formation with or without nephrocalcinosis. Children with type 3 Bartter syndrome can exhibit a mixed Bartter-Gitelman phenotype consistent with the role of this chloride ion channel in both the TALH and DCT. Type 4 Bartter syndrome is associated with sensorineural deafness given the role of Barttin, CLC-Ka, and CLC-Kb in the marginal cells of the scala media of the inner ear [62].

Calcium-sensing receptor (CaSR) The CASR gene, located on chromosome 3q13.3-q21, encodes for a plasma membrane G-protein-coupled receptor known as the calciumsensing receptor (CaSR), which is stimulated by divalent ions such as calcium and magnesium [65]. The CaSR plays a role in regulation of PTH secretion and in renal tubular calcium reabsorption in response to alterations in extracellular calcium concentrations. It is expressed in the basolateral side of the cortical TALH, and its stimulation by elevated peritubular levels of reabsorbed calcium induces an inhibition of NKCC 2 and ROMK, resulting in decreased sodium absorption and subsequently calcium absorption [65-67]. Pearce et al. [68] described six kindreds with an autosomal dominant inheritance of hypocalcemia and hypercalciuria resulting from an activating mutations of the CASR gene. Activating mutations of the CASR gene give rise to hypercalciuria and hypocalcemia because of the direct effect in TALH cells (where the CaSR can inhibit calcium absorption) and to the inhibition of PTH secretion, which induces additional downregulation of calcium absorption in the distal tubule. The inhibition of the NKCC2 transporter and ROMK channel leads to a Bartter syndrome type 5. Children will present with hypocalcemia (usually mild and asymptomatic but at times with carpopedal spasm and seizures), hypercalciuria, and polyuria, and about half may have associated hypomagnesemia [68-70]. The key feature to note is that therapy of hypocalcemia with vitamin
D or calcium dramatically increases urinary calcium excretion. This will further lead to polyuria, nephrocalcinosis, nephrolithiasis, and reduction in renal function, which may be partially reversible following cessation of treatment [68]. Thus, it is important to identify subjects with gain-offunction CASR mutation, and in these patients, Vitamin D therapy should be restricted to symptomatic patients only, with careful follow-up of urine calcium excretion and consideration of anticalciuric diuretics [71].

Familial hypomagnesemia with hypercalciuria and nephrocalcinosis (FHHNC) FHHNC, or Michelis-Castrillo syndrome [72], is a rare tubular disorder. It is inherited as an autosomal recessive disorder causing mutations in the PCLN1 gene on 3q27, which encodes for the protein claudin 16/ paracellin-1 $[73,74]$. Claudins are membrane proteins that are believed to play an important role in the integrity of the tight junction. Paracellin-1, a member of the claudin family, is expressed in the tight junctions of the TALH in humans [75]. The defect in paracellin-1 function interferes with the paracellular absorption of calcium and magnesium in the TALH.

FHHNC presents at birth. It is characterized by magnesium and calcium wasting, resulting in persistent hypomagnesemia (presents with neonatal seizures), marked hypercalciuria leading to early nephrocalcinosis, incomplete distal renal tubular acidocis (dRTA), hypocitraturia, urinary tract infections, polyuria, and progressive renal failure [7377]. Some children with FHHNC have ocular abnormalities, such as severe myopia, nystagmus, and chorioretinitis [78]. Children reach end stage by their teenage or youngadult years. The serum calcium level remains in the normal range. Hypocalcemia is possibly prevented by increased transcellular tubular calcium absorption in the distal tubule, intestinal calcium absorption, and calcium release out of bone, mediated by different hormones such as $1,25-(\mathrm{OH})_{2}-$ $\mathrm{D}_{3}$ and PTH. The serum PTH is elevated during the course of disease and precedes the impairment in GFR. The reduced concentrating ability, incomplete dRTA, recurrent urinary tract infections, and the development of renal insufficiency are not believed to result directly from the genetic defect but rather as a consequence of medullary interstitial damage from nephrocalcinosis. Children with FHHNC do not have clinically significant salt wasting or hypokalemic metabolic alkalosis and have normal renin and aldosterone levels, which helps to differentiate this entity from Bartter syndrome [75, 79]. The elevated serum PTH helps in differentiating it from Dent's disease.

\section{Distal renal tubule and hypercalciuria}

The fine tuning of calcium excretion occurs in the distal part of the nephron in the DCT, connecting tubule and 
cortical collecting duct. Calcium absorption occurs in the principal cells through an active transcellular pathway (Fig. 3). Pseudohypoaldosteronism (PHA) type II from with-no-lysine kinase 4 (WNK-4) mutation can cause hypercalciuria from its role in regulation of TRPV5, whereas dRTA leads to hypercalciuria indirectly from metabolic acidosis and increased bone resorption.

Pseudohypoaldosteronism type II (PHA II) PHA type II is a genetic disorder due to mutations in the gene encoding WNK-1 or -4 , which produces a clinical phenotype of hypertension, hyperkalemia, and metabolic acidosis. Mayan et al. [80] described a family with WNK4 gene mutation was associated with marked hypercalciuria (and osteopenia) that was responsive to thiazide diuretics. Jiang et al. [81] recently showed that WNK4 positively regulates TRPV5mediated calcium transport, which could account for the observed hypercalciuria.

Primary distal renal tubular acidosis (dRTA) Primary dRTA is a hereditary disorder characterized by impaired renal acid secretion resulting in hyperchloremic metabolic acidosis, hypokalemia, hypercalciuria, hypocitraturia, and inappropriately high urinary $\mathrm{pH}$. The acidification of urine at the distal tubule involves multiple proteins composed of the vacuolar $\mathrm{H}^{+}$-ATPase, the band 3-anion exchanger 1 (AE1) $\left(\mathrm{Cl}^{-} / \mathrm{HCO}_{3}^{-}\right)$, and carbonic anhydrase II. Thus, dRTA can occur following mutation in the SLC4A1gene for the AE1 in autosomal dominant dRTA $[82,83]$, in the gene ATP6V1B1 coding for $\beta$ subunit of the vacuolar $\mathrm{H}^{+}$-ATPase (located in chromosome $2 \mathrm{p} 13$ ) in autosomal recessive dRTA with sensorineural deafness [84, 85], and in the gene ATP6VOA4 (located on chromosome 7q33-34) for $\alpha$ subunit of the vacuolar $\mathrm{H}^{+}$-ATPase in autosomal recessive dRTA without sensorineural deafness [86]. Mixed RTA can arise from mutation in CAII gene for carbonic anhydrase II enzyme [87, 88]. Primary dRTA produces a profound metabolic acidosis, growth retardation, and impressive hypercalciuria, nephrolithiasis, and nephrocalcinosis. The hypercalciuria is believed to be secondary from the increased buffering function of the bone and direct effect of metabolic acidosis on calcium absorption, and the development of progressive nephrocalcinosis is further aggravated by the associated hypocitraturia.

\section{Idiopathic hypercalciuria: absorptive, renal, and resorptive hypercalciuria (role of vitamin $D$, vitamin D receptor, PTH, and cytokines)}

Pak et al. [89] introduced a tripartite classification of absorptive, renal, and resorptive hypercalciuria for idiopathic hypercalciuria. Over the years, investigators have further modified the classification based on urine calcium excretion, serum phosphate, and serum PTH secretion during fasting and after a calcium load [90]. It is now postulated that idiopathic hypercalciuria can occur from either or in combination with an (1) increased intestinal calcium absorption mediated either by a direct increase in calcium absorption (type 1 absorptive hypercalciuria) or through excess $1,25-(\mathrm{OH})_{2} \mathrm{D}_{3}$-mediated calcium absorption (type II absorptive hypercalciuria); (2) decreased renal absorption of either calcium (renal hypercalciuria) or phosphorus (type III absorptive hypercalciuria); (3) enhanced bone resorption (resorptive hypercalciuria) [91-93]. Maierhofer et al. [94] showed that administration of 1,25$(\mathrm{OH})_{2} \mathrm{D}_{3}$ while eating a normal-calcium diet in healthy subjects led to an increase in intestinal calcium absorption and an increase in urinary calcium excretion, concluding that the key components of idiopathic hypercalciuria are related to calcitriol. They also showed that increased calcitriol administration in humans on a calcium restricted diet leads to negative calcium balance from increased urinary calcium loss mediated through increased bone resorption [95]. Similarly, vitamin D toxicity gives rise to hypercalcemia and hypercalciuria by stimulating intestinal calcium absorption. It is important to remember that hypercalciuria usually precedes hypercalcemia as an indicator of vitamin D overdose [96]. A fair number of investigators have observed that blood calcitriol concentration is, on average, higher in patients with idiopathic hypercalciuria or inappropriately normal for the condition compared with healthy subjects. Kaplan et al. [97] found elevated calcitriol levels in one third of absorptive hypercalciuria patients and normal values in two thirds, which may be considered as inappropriately high given the presence of relative hypoparathyroidism. Zerwekh and Pak [98] observed that in both renal and absorptive hypercalciuric subjects on thiazides, urine calcium excretion was normalized, but only the renal hypercalciuric group showed a decrease in intestinal hyperabsorption, PTH, and calcitriol level, whereas no changes were observed in the absorptive hypercalciuric subjects. These results would support different inciting events in development of hypercalciuria, namely, primary calcium leak in renal hypercalciuria and abnormal $1,25-(\mathrm{OH})_{2}-\mathrm{D}_{3}$ metabolism in absorptive hypercalciuria.

Data from NPT2a ${ }^{-} /$mice that lack the $\mathrm{Na}^{+} / \mathrm{Pi}$ cotransporter have provided further insight into the role of $1,25-(\mathrm{OH})_{2}-\mathrm{D}_{3}$ in the development of hypercalciuria. The primary defect in tubular phosphate absorption in NPT2 $\mathrm{a}^{-} \Gamma^{-}$ mice stimulates calcitriol synthesis by the kidney, which in turn increases intestinal absorption of calcium and phosphate and inhibits PTH secretion, resulting in hypercalciuria [45]. A disruption in the $1 \alpha$-hydroxylase gene in NPT $2 \mathrm{a}^{-} \digamma$ mice decreases urinary calcium excretion and prevents develop- 
ment of nephrolithiasis, signifying the importance of increased calcitriol synthesis in the development of hypercalciuria [99]. Similarly, in subjects with hypophosphatemic tubular disorder such as X-linked hypophosphatemic rickets (PHEX) and autosomal dominant hypophosphatemic rickets (FGF-23) with decreased production of calcitriol due to the inhibitory effect of FGF-23, no hypercalciuria is observed until therapy with calcitriol is instituted [100, 101]. Studies on the genetic hypercalciuric stone-forming (GHS) rat model suggest a role for an increase in number and/or function of vitamin D receptors (VDR) in enterocyte [102, 103]. Favus et al. [104] found an elevation in tissue VDR level in patients with idiopathic hypercalciuria with normal calcitriol level.

From studies done on GHS rats, it seems that the role of bone in the development of hypercalciuria appears to be as equally important as the intestines. While on a low-calcium diet, GHS rats continue to have markedly elevated urine calcium excretion exceeding their dietary intake, suggesting a role for increased bone resorption. Krieger et al. [105] showed that bone in GHS rats is sensitive to $1,25-(\mathrm{OH})_{2} \mathrm{D}_{3^{-}}$ induced bone resorption, and Bushinsky et al. [106] showed that alendronate decreases urine calcium excretion in GHS rats on a low-calcium diet to a level below their dietary intake (Fig. 4). Weisinger et al. [107] found alendronate to decrease urine calcium excretion in adults with hypercalciuria, and Freundlich and Alon [abstract to be presented at 14th International Pediatric Nephrology Association (IPNA) 2007 meeting] recently reported preliminary similar outcome in osteopenic hypercalciuric children. Cytokines are known to induce bone resorption and inhibit bone

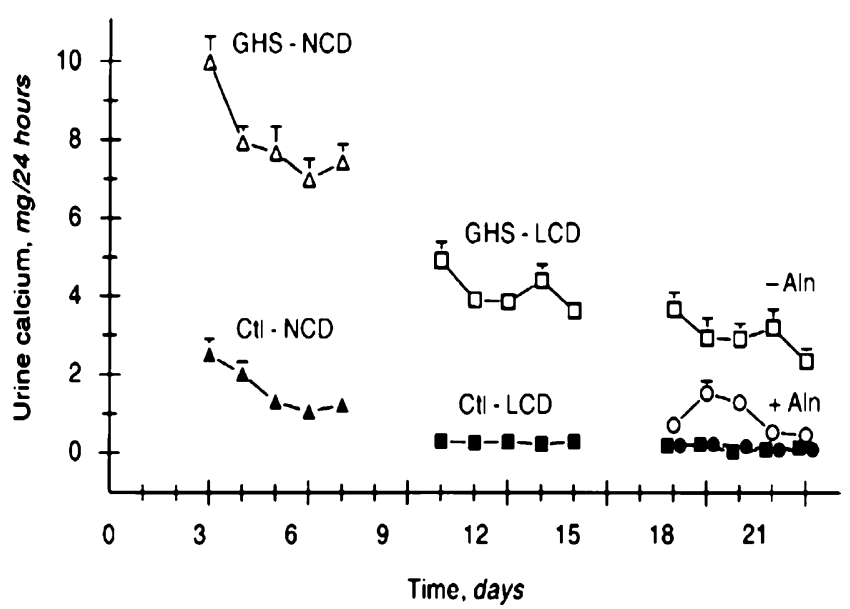

Fig. 4 Urine calcium excretion in genetic hypercalciuric stoneforming (GHS) and control (Ctl) rats. Alendronate led to a significant decrease in urine calcium in the GHS, but not in the Ctl rats. GHS rats (open symbols), Ctl rats (closed symbols), NCD normal-calcium diet ( $1.2 \%$ calcium, triangles $), L C D$ low-calcium diet $(0.02 \%$ calcium, squares), $L C D+A \ln$ alendronate (Aln, $50 \mathrm{~g} / \mathrm{kg}$ per $24 \mathrm{~h}$, circles). Used with permission [106] formation and may play a role in the rare of "resorptive hypercalciuria", in which a primary bone disorder is believed to be the inciting defect. Ghazali et al. [108] found cytokines such as interleukin (IL)- $1 \beta$, IL-6, tumor necrosis factor (TNF)- $\alpha$, and granulocyte, macrophage stimulating factor to be increased in hypercalciuric calcium-stone-forming subjects with increased bone loss. Similar findings have been reported by Pacifici et al. [109], which allude to a role for cytokines in the development of hypercalciuria.

Hypercalciuria is a complex polygenic trait, and it is possible that absorptive and renal forms of hypercalciuria may represent a continuum of a single disease $[110,111]$. When adults with idiopathic hypercalciuria are placed on a low-calcium diet, there is a continuum from those who are in "positive calcium balance", suggesting a component of direct increased intestinal calcium absorption, to those in "negative calcium balance", suggesting other mechanisms of hypercalciuria [110]. The lack of evidence of increased bone turnover in children with hypercalciuria suggests that renal and absorptive hypercalciuria may not be distinct physiologic entities [112]. An oral calcium loading test was popular in the past to differentiate between the different forms of idiopathic hypercalciuria; it has recently come under challenge [91, 113]. In children, Aladjem et al. [114] reevaluated calcium-loading tests after an interval of 37 years in children who were initially diagnosed as having absorptive or renal hypercalciuria and found a different result in more than half of the children studied. However, the classification, although not practical, has allowed investigators to develop a structured approach to the understanding of hypercalciuria.

\section{Association of hypercalciuria with osteoporosis}

A cross-sectional study from the Third National Health and Nutrition Examination Survey (NHANES III) showed that men (data weaker for women) with kidney-stone history had lower femoral neck BMD than did men without kidney stones after adjusting for age, body mass index (BMI), ethnicity, and other potential confounders, with a concomitant higher prevalence of wrist and spine fractures [115]. In a prospective study, Asplin et al. [116] found that the severity of urine calcium excretion best predicted bone loss in idiopathic hypercalciuric stone formers. Vezzoli et al. [117] observed lower BMD in hypercalciuric compared with normocalciuric stone-forming women, even in the presence of increased intestinal calcium absorption documented by strontium absorption. Similarly, Pietschmann et al. [118] found lower spinal BMD in hypercalciuric compared with normocalciuric stone formers. In contrast, 
Jaeger et al. [119] and Barkin et al. [120] found no difference in BMD between normocalciuric and hypercalciuric stone formers.

When hypercalciuric stone formers were studied based on Pak's classification, the decrease in BMD was more frequent and greater in patients with renal hypercalciuria than in those with absorptive hypercalciuria [120, 121]. Other studies observed no reduction in BMD in absorptive hypercalciuria $[122,123]$. The overall trend in the literature on adults with hypercalciuria, with or without stone disease, would suggest that they have lower BMD, but the results may vary based on subgroup analysis such as normocalciuric versus hypercalciuric stone formers or between renal versus absorptive hypercalciuria.

Penido et al. [124] found lower BMD in children with idiopathic hypercalciuria, and in a subsequent study [125], they found that these findings were more marked in children with hypocitraturia in addition to the hypercalciuria. GarciaNeto et al. [126] had also made similar observation in an earlier study but made an interesting observation of negative linear correlation between age and bone mineral content in children with idiopathic hypercalciuria, namely, the $\mathrm{Z}$ score for BMD was much lower in older children with hypercalciuria, which raises the issue of whether adult osteoporosis has its origin in childhood. Similarly, Freundlich et al. [127] showed that reduced BMD was present in children with hypercalciuria and concomitantly found a high incidence of both hypercalciuria and reduced BMD in their asymptomatic mothers. The data in both children and adults indicate that the risk for bone loss is present in patients with hypercalciuria, and its origin may lie in childhood; hence, one must consider monitoring bone density as a proxy for calcium balance in children.

\section{Diet in hypercalciuria (or physiological hypercalciuria)}

Diet can have a significant impact on calcium handling by the renal tubules. Urinary calcium excretion is significantly affected by sodium, protein, potassium, phosphorous, and calcium in the diet. Ninety percent of calcium absorption occurs as a paracellular event in the proximal tubule and TALH, which places calcium absorption at the mercy of sodium absorption. An increase in calcium delivery to the distal nephron for transcellular absorption can overwhelm the distal nephron, leading to obligatory hypercalciuria. An increase in either oral or intravenous sodium chloride inhibits net renal tubular calcium absorption and is used with beneficial effect in the treatment of hypercalcemia to increase urinary calcium excretion. The average consumption of salt in industrialized countries is $10 \mathrm{~g}$ (or $170 \mathrm{mmol}$ $\mathrm{Na}$ )/day per person as determined by urinary 24 -h excretion in the INTERSALT study [128]. Nordin et al. [129] have shown that approximately $1 \mathrm{mmol}$ (or $40 \mathrm{mg}$ ) calcium is excreted for every $100 \mathrm{mmol}$ (or $2.3 \mathrm{~g}$ ) of sodium. There is a reproducible linear positive correlation between urinary sodium (a surrogate for dietary intake) and calcium excretion in stone formers as well as in normal individuals [130]. Thus, a diet high in sodium can lead to hypercalciuria [131].

An increase in dietary protein intake increases net acid excretion because of the release of protons from oxidation of sulfur in the amino acids methionine, cysteine, and cystine [132]. Conversely, dietary potassium found mostly in the form of potassium salts of metabolizable organic anions in vegetable and fruits, reflects the dietary intake of actual bicarbonate or potential bicarbonate, which reduce net acid excretion [133]. Urine calcium excretion increases as net acid excretion increases; hence, it rises progressively as the protein intake increases. The increment in urinary calcium excretion is $\sim 0.04 \mathrm{mmol}(\sim 1.6 \mathrm{mg})$ calcium per gram of protein. The increase in calcium excretion with dietary protein is more marked in calcium-stone formers than in healthy subjects $[91,134]$. Similarly in healthy subjects, an increase in dietary calcium increases urine calcium excretion by $6-7 \%$ of the dietary intake increment, whereas the change in calcium-stone formers is almost twice for the same increase in calcium intake [133]. A severe dietary phosphate deprivation induces increased calcium excretion, probably by activating the vitamin $\mathrm{D}$ endocrine system and thereby enhancing intestinal calcium absorption when calcium is available in the diet, or bone resorption when dietary calcium is low [94, 95, 135].

In the management of hypercalciuric stone formers, close attention must be paid to dietary intake and corrections made for dietary errors. Dietary hypercalciuria linked to excessive intakes of sodium, protein, or calcium or to deficiency in potassium or phosphate intake is diagnosed when calcium excretion is high while the patient is on his/her usual diet and normalizes during optimal dietary conditions. Thus, it appears that the more society deviates from the traditional balanced diet with optimal intake of protein, salt, fruits, and vegetables, replacing them with sodium-rich fast foods and artificial drinks, accompanied by a decrease in intake of potassium-rich fruits and vegetables, and increase in protein intake, the higher is the risk for "physiological hypercalciuria" [136].

\section{Approach to and management of hypercalciuria}

Hypercalciuria in children can present as nonglomerular hematuria (gross or microscopic), noninfectious dysuria, urinary frequency and dysuria, abdominal and back pain, or with urolithiasis [137, 138]. It can be intermittent or 
persistent, a transient phenomenon or associated with a family history of urolithiasis. Once hypercalciuria is detected in a child, a secondary etiology should be considered, as successful correction of hypercalciuria in such cases depends on eradication of the primary cause. An evaluation for the rare monogenic disorders characterized by hypercalciuria should be considered in the presence of positive family history, failure to thrive, growth retardation, rickets, acid-base disturbances, renal dysfunction, proteinuria, electrolyte imbalance, dysmorphic features, or poor response to therapy.

Hypercalciuria, like blood pressure, is defined in children as urinary calcium excretion of $>4 \mathrm{mg} / \mathrm{kg}$ per day on a "statistical" basis, whereas in adults, hypercalciuria is defined as $>250 \mathrm{mg} /$ day in women and $>300 \mathrm{mg} /$ day in men as an "outcome" value observed in most calcium-stone formers. The statistical cutoffs of $24-\mathrm{h}$ urine $>4 \mathrm{mg} / \mathrm{kg}$ per day or urine calcium/creatinine ratio $>0.21$ and their clinical implications have been recently addressed in detail by Butani and Kalia [139]. They raise many questions about planning a strategy for therapy in children. We believe that only symptomatic hypercalciuric children should be treated with pharmacological agents, whereas nonpharmacological intervention (vide infra) can be used more liberally.

When idiopathic hypercalciuria is confirmed in symptomatic children, we recommend as the first step to assess whether dietary manipulation can normalize calcium excretion. We recommend a Dietary Reference Intake for protein and calcium that is not excessive in salt (2.0-2.4 g) per day and supplemented with at least the recommended daily allowance of five to six servings of fruits and vegetables (3.0-3.5 g potassium) per day. Compliance with these dietary recommendations can be assessed by measuring urine $\mathrm{Na}^{+} / \mathrm{K}$ ratio, which should be $<2.5$. The dietary implications of salt, protein, and fruits and vegetables in hypercalciuria are well known, but we are cognizant of the fact that children may not fully comply with such dietary manipulations nor with the traditional recommendation of high fluid intake [4]. If in 4-6 weeks hypercalciuria persists, treatment with potassium citrate at $1-1.5 \mathrm{mEq}$ of potassium per kilogram per day is recommended. If the child fails to tolerate potassium citrate or hypercalciuria fails to correct, a thiazide diuretic can be added [4, 136]. Chlorothiazide $15-25 \mathrm{mg} / \mathrm{kg}$ per day or hydrochlorothiazide $1.5-2.5 \mathrm{mg} / \mathrm{kg}$ per day can be used. In the past, it was proposed that thiazide-induced hypocalciuria occurred from volume contraction, which through increased proximal sodium absorption would increase the passive calcium absorption. Costanzo et al. [140] showed that acute administration of chlorothiazide in the tubular lumen stimulated transcellular calcium transport in the DCT. The earlier observation made by Costanzo et al. was recently confirmed by Jang et al. [141], who showed that thiazides increased the expression of TRPV5 and calbindin-D(28K) and decreased expression of sodium-chloride cotransporter in the DCT, leading to increased calcium absorption in the DCT. Children on long-term thiazide diuretics will need to be monitored for dyselectrolytemia, hyperlipidemia, and hyperglycemia. One can consider adding amiloride, as it further increases the hypocalciuric effect and decreases potassium and magnesium loss. Contrary to past practice, dietary restriction of calcium is not recommended in children with hypercalciuria, as it puts the growing child at risk for negative calcium balance and poor bone mineralization. It may also increase urinary excretion of oxalate from increased gastrointestinal absorption of oxalate resulting from decreased luminal calcium present to bind with oxalate. For risk of possible negative calcium balance, drugs such as sodium cellulose phosphate, a nonabsorbable ion-exchange resin used for complexing intestinal calcium, are not used in children. Phosphate salts can be used in children with hypercalciuria due to tubular phosphate leak. In children with hypercalciuria secondary to renal tubular acidosis, potassium citrate is the drug of choice for treatment of hypercalciuria. At times, this may need to be supplemented by sodium bicarbonate and calcium-sparing diuretics.

In summary, a better understanding of the rare inherited renal tubular disorders associated with hypercalciuria has improved our understanding of calcium handling by the kidney and development of hypercalciuria. On the other hand, our understanding of the more common idiopathic hypercalciuria, probably inherited as a polygenic trait and affected by the environment, remains dismal, and even more so in children. Many questions remain open: Is dietary manipulation adequate for all children, or should a subset of children be offered anticalciuric therapy given that dietary manipulation will not suffice or is not needed in them? Should all children be treated with anticalciuric therapy? Once an anticalciuric therapy is initiated, then for how long should it be continued? The data on BMD is suggestive of poor bone health in hypercalciuria; therefore, should all children have a dual-energy X-ray absorptiometry (DXA) scan with all its known pitfalls in children? Should DXA findings be considered in planning therapy for hypercalciuria in children? There are many such questions with respect to hypercalcuria in children that need to be addressed. We encourage the pediatric nephrology community to further address these issues in the hope of developing evidencebased care.

Acknowledgment The study was supported by the "Sam and Helen Kaplan Research Fund in Pediatric Nephrology" and "The Eric McClure Research Fund in Pediatric Bone and Mineral Diseases". We are thankful to Mrs. Birdie Dean for her excellent secretarial assistance. 


\section{References}

1. Albright F, Henneman P, Benedict PH, Forbes AP (1953) Idiopathic hypercalciuria: a preliminary report. Proc $\mathrm{R}$ Soc Med 46:1077-1081

2. Edvardsson V, Elidottir H, Indridason OS, Palsson R (2005) High incidence of kidney stones in Icelandic children. Pediatr Nephrol 20:940-944

3. Stapleton FB, McKay CP, Noe HN (1987) Urolithiasis in children: the role of hypercalciuria. Pediatr Ann 16:980-992

4. Alon US, Zimmerman H, Alon M (2004) Evaluation and treatment of pediatric idiopathic urolithiasis-revisited. Pediatr Nephrol 19:516-520

5. Curhan GC, Willett WC, Speizer FE, Stampfer MJ (2001) Twenty-four-hour urine chemistries and the risk of kidney stones among women and men. Kidney Int 59:2290-2298

6. Coe FL, Evan A, Worcester E (2005) Kidney stone disease. $\mathrm{J}$ Clin Invest 115:2598-2608

7. Curhan GC, Willett WC, Rimm EB, Stampfer MJ (1997) Family history and risk of kidney stones. J Am Soc Nephrol 8:1568-1573

8. Polito C, La Manna A, Cioce F, Villani J, Nappi B, Di Toro R (2000) Clinical presentation and natural course of idiopathic hypercalciuria in children. Pediatr Nephrol 15:211-214

9. Reed BY, Heller HJ, Gitomer WL, Pak CY (1999) Mapping a gene defect in absorptive hypercalciuria to chromosome 1q233q24. J Clin Endocrinol Metab 84:3907-3913

10. Reed BY, Gitomer WL, Heller HJ, Hsu MC, Lemke M, Padalino P, Pak CY (2002) Identification and characterization of a gene with base substitutions associated with the absorptive hypercalciuria phenotype and low spinal bone density. J Clin Endocrinol Metab 87:1476-1485

11. Vezzoli G, Tanini A, Ferrucci L, Soldati L, Bianchin C, Franceschelli F, Malentacchi C, Porfirio B, Adamo D, Terranegra A, Falchetti A, Cusi D, Bianchi G, Brandi ML (2002) Influence of calcium-sensing receptor gene on urinary calcium excretion in stone-forming patients. J Am Soc Nephrol 13:2517-2523

12. Imamura K, Tonoki H, Wakui K, Fukushima Y, Sasaki S, Yausda K, Takekoshi Y, Tochimaru H (1998) 4q33-qter deletion and absorptive hypercalciuria: report of two unrelated girls. Am J Med Genet 78:52-54

13. Giuffre M, La Placa S, Carta M, Cataliotti A, Marino M, Piccione M, Pusateri F, Meli F, Corsello G (2004) Hypercalciuria and kidney calcifications in terminal $4 \mathrm{q}$ deletion syndrome: further evidence for a putative gene on $4 \mathrm{q}$. Am J Med Genet A 126:186-190

14. Moe OW, Bonny O (2005) Genetic hypercalciuria. J Am Soc Nephrol 16:729-745

15. Resnick M, Pridgen DB, Goodman HO (1968) Genetic predisposition to formation of calcium oxalate renal calculi. $\mathrm{N}$ Engl $\mathrm{J}$ Med 278:1313-1318

16. Loredo-Osti JC, Roslin NM, Tessier J, Fujiwara TM, Morgan K, Bonnardeaux A (2005) Segregation of urine calcium excretion in families ascertained for nephrolithiasis: evidence for a major gene. Kidney Int 68:966-971

17. Hoenderop JG, van der Kemp AW, Hartog A, van de Graaf SF, van Os CH, Willems PH, Bindels RJ (1999) Molecular identification of the apical $\mathrm{Ca} 2+$ channel in 1, 25-dihydroxyvitamin D3-responsive epithelia. J Biol Chem 274:8375-8378

18. Reichel H, Koeffler HP, Norman AW (1989) The role of the vitamin D endocrine system in health and disease. N Engl J Med 320:980-991

19. Peng JB, Chen XZ, Berger UV, Weremowicz S, Morton CC, Vassilev PM, Brown EM, Hediger MA (2000) Human calcium transport protein CaT1. Biochem Biophys Res Commun 278:326-332
20. Muller D, Hoenderop JG, Merkx GF, van Os CH, Bindels RJ (2000) Gene structure and chromosomal mapping of human epithelial calcium channel. Biochem Biophys Res Commun 275:47-52

21. Peng JB, Chen XZ, Berger UV, Vassilev PM, Tsukaguchi H, Brown EM, Hediger MA (1999) Molecular cloning and characterization of a channel-like transporter mediating intestinal calcium absorption. J Biol Chem 274:22739-22746

22. Hoenderop JG, Hartog A, Stuiver M, Doucet A, Willems PH, Bindels RJ (2000) Localization of the epithelial $\mathrm{Ca}(2+)$ channel in rabbit kidney and intestine. J Am Soc Nephrol 11: $1171-1178$

23. Hoenderop JG, Vennekens R, Muller D, Prenen J, Droogmans G, Bindels RJ, Nilius B (2001) Function and expression of the epithelial $\mathrm{Ca}(2+)$ channel family: comparison of mammalian $\mathrm{ECaC1}$ and 2. J Physiol 537:747-761

24. Frick KK, Bushinsky DA (2003) Molecular mechanisms of primary hypercalciuria. J Am Soc Nephrol 14:1082-1095

25. Loffing J, Loffing-Cueni D, Valderrabano V, Klausli L, Hebert SC, Rossier BC, Hoenderop JG, Bindels RJ, Kaissling B (2001) Distribution of transcellular calcium and sodium transport pathways along mouse distal nephron. Am J Physiol Renal Physiol 281:F1021-F1027

26. Reilly RF, Ellison DH (2000) Mammalian distal tubule: physiology, pathophysiology, and molecular anatomy. Physiol Rev 80:277-313

27. Suki WN (1979) Calcium transport in the nephron. Am J Physiol 237:F1-F6

28. Shimizu T, Yoshitomi K, Nakamura M, Imai M (1990) Effects of $\mathrm{PTH}$, calcitonin, and cAMP on calcium transport in rabbit distal nephron segments. Am J Physiol 259:F408-F414

29. Bindels RJ, Hartog A, Timmermans J, Van Os CH (1991) Active $\mathrm{Ca} 2+$ transport in primary cultures of rabbit kidney $\mathrm{CCD}$ : stimulation by 1,25-dihydroxyvitamin D3 and PTH. Am J Physiol 261:F799-F807

30. Hoenderop JG, van Leeuwen JP, van der Eerden BC, Kersten FF, van der Kemp AW, Merillat AM, Waarsing JH, Rossier BC, Vallon V, Hummler E, Bindels RJ (2003) Renal Ca2+ wasting, hyperabsorption, and reduced bone thickness in mice lacking TRPV5. J Clin Invest 112:1906-1914

31. Scheinman SJ (1998) X-linked hypercalciuric nephrolithiasis: clinical syndromes and chloride channel mutations. Kidney Int $53: 3-17$

32. Lloyd SE, Pearce SH, Gunther W, Kawaguchi H, Igarashi T, Jentsch TJ, Thakker RV (1997) Idiopathic low molecular weight proteinuria associated with hypercalciuric nephrocalcinosis in Japanese children is due to mutations of the renal chloride channel (CLCN5). J Clin Invest 99:967-974

33. Gunther W, Luchow A, Cluzeaud F, Vandewalle A, Jentsch TJ (1998) ClC-5, the chloride channel mutated in Dent's disease, colocalizes with the proton pump in endocytotically active kidney cells. Proc Natl Acad Sci USA 95:8075-8080

34. Devuyst O, Christie PT, Courtoy PJ, Beauwens R, Thakker RV (1999) Intra-renal and subcellular distribution of the human chloride channel, CLC-5, reveals a pathophysiological basis for Dent's disease. Hum Mol Genet 8:247-257

35. Nykjaer A, Dragun D, Walther D, Vorum H, Jacobsen C, Herz J, Melsen F, Christensen EI, Willnow TE (1999) An endocytic pathway essential for renal uptake and activation of the steroid 25- $(\mathrm{OH})$ vitamin D3. Cell 96:507-515

36. Leheste JR, Melsen F, Wellner M, Jansen P, Schlichting U, Renner-Muller I, Andreassen TT, Wolf E, Bachmann S, Nykjaer A, Willnow TE (2003) Hypocalcemia and osteopathy in mice with kidney-specific megalin gene defect. FASEB J 17:247-249

37. Wang SS, Devuyst O, Courtoy PJ, Wang XT, Wang H, Wang Y, Thakker RV, Guggino S, Guggino WB (2000) Mice lacking renal 
chloride channel, CLC-5, are a model for Dent's disease, a nephrolithiasis disorder associated with defective receptor-mediated endocytosis. Hum Mol Genet 9:2937-2945

38. Silva IV, Cebotaru V, Wang H, Wang XT, Wang SS, Guo G, Devuyst O, Thakker RV, Guggino WB, Guggino SE (2003) The ClC-5 knockout mouse model of Dent's disease has renal hypercalciuria and increased bone turnover. J Bone Miner Res $18: 615-623$

39. Reinhart SC, Norden AG, Lapsley M, Thakker RV, Pang J, Moses AM, Frymoyer PA, Favus MJ, Hoepner JA, Scheinman SJ (1995) Characterization of carrier females and affected males with X-linked recessive nephrolithiasis. J Am Soc Nephrol 5:1451-1461

40. Wrong OM, Norden AG, Feest TG (1994) Dent's disease; a familial proximal renal tubular syndrome with low-molecularweight proteinuria, hypercalciuria, nephrocalcinosis, metabolic bone disease, progressive renal failure and a marked male predominance. QJM 87:473-493

41. Igarashi $\mathrm{T}$, Hayakawa $\mathrm{H}$, Shiraga $\mathrm{H}$, Kawato $\mathrm{H}$, Yan $\mathrm{K}$, Kawaguchi H, Yamanaka T, Tsuchida S, Akagi K (1995) Hypercalciuria and nephrocalcinosis in patients with idiopathic low-molecular-weight proteinuria in Japan: is the disease identical to Dent's disease in United Kingdom? Nephron 69:242-247

42. Raja KA, Schurman S, D'mello RG, Blowey D, Goodyer P, Van Why S, Ploutz-Snyder RJ, Asplin J, Scheinman SJ (2002) Responsiveness of hypercalciuria to thiazide in Dent's disease. $\mathrm{J}$ Am Soc Nephrol 13:2938-2944

43. Tieder M, Modai D, Shaked U, Samuel R, Arie R, Halabe A, Maor J, Weissgarten J, Averbukh Z, Cohen N (1987) "Idiopathic" hypercalciuria and hereditary hypophosphatemic rickets. Two phenotypical expressions of a common genetic defect. N Engl J Med 316:125-129

44. Murer H, Hernando N, Forster I, Biber J (2000) Proximal tubular phosphate reabsorption: molecular mechanisms. Physiol Rev 80:1373-1409

45. Beck L, Karaplis AC, Amizuka N, Hewson AS, Ozawa H, Tenenhouse HS (1998) Targeted inactivation of Npt2 in mice leads to severe renal phosphate wasting, hypercalciuria, and skeletal abnormalities. Proc Natl Acad Sci USA 95:53725377

46. Alon U, Hellerstein S (1994) Assessment and interpretation of the tubular threshold for phosphate in infants and children. Pediatr Nephrol 8:250-251

47. Khundmiri SJ, Rane MJ, Lederer ED (2003) Parathyroid hormone regulation of type II sodium-phosphate cotransporters is dependent on an A kinase anchoring protein. J Biol Chem 278:10134-10141

48. Bowe AE, Finnegan R, Jan de Beur SM, Cho J, Levine MA, Kumar R, Schiavi SC (2001) FGF-23 inhibits renal tubular phosphate transport and is a PHEX substrate. Biochem Biophys Res Commun 284:977-981

49. Saito H, Kusano K, Kinosaki M, Ito H, Hirata M, Segawa H, Miyamoto K, Fukushima N (2003) Human fibroblast growth factor-23 mutants suppress $\mathrm{Na}+$-dependent phosphate cotransport activity and 1alpha,25-dihydroxyvitamin D3 production. J Biol Chem 278:2206-2211

50. Segawa H, Kaneko I, Takahashi A, Kuwahata M, Ito M, Ohkido I, Tatsumi S, Miyamoto K (2002) Growth-related renal type II $\mathrm{Na} / \mathrm{Pi}$ cotransporter. J Biol Chem 277:19665-19672

51. Ohkido I, Segawa H, Yanagida R, Nakamura M, Miyamoto K (2003) Cloning, gene structure and dietary regulation of the typeIIc $\mathrm{Na} / \mathrm{Pi}$ cotransporter in the mouse kidney. Pflugers Arch 446:106-115

52. Tenenhouse HS, Roy S, Martel J, Gauthier C (1998) Differential expression, abundance and regulation of $\mathrm{Na}+$-phosphate cotransporter genes in murine kidney. Am J Physiol 44:F527-F534
53. Prie D, Huart V, Bakouh N, Planelles G, Dellis O, Gerard B, Hulin P, Benque-Blanchet F, Silve C, Grandchamp B, Friedlander G (2002) Nephrolithiasis and osteoporosis associated with hypophosphatemia caused by mutations in the type 2a sodiumphosphate cotransporter. N Engl J Med 347:983-991

54. Lapointe JY, Tessier J, Paquette Y, Wallendorff B, Coady MJ, Pichette V, Bonnardeaux A (2006) NPT2a gene variation in calcium nephrolithiasis with renal phosphate leak. Kidney Int 69:2261-2267

55. Jones A, Tzenova J, Frappier D, Crumley M, Roslin N, Kos C, Tieder M, Langman C, Proesmans W, Carpenter T, Rice A, Anderson D, Morgan K, Fujiwara T, Tenenhouse H (2001) Hereditary hypophosphatemic rickets with hypercalciuria is not caused by mutations in the Na/Pi cotransporter NPT2 gene. J Am Soc Nephrol 12:507-514

56. van den Heuvel L, Op de Koul K, Knots E, Knoers N, Monnens L (2001) Autosomal recessive hypophosphataemic rickets with hypercalciuria is not caused by mutations in the type II renal sodium/phosphate cotransporter gene. Nephrol Dial Transplant $16: 48-51$

57. Bergwitz C, Roslin NM, Tieder M, Loredo-Osti JC, Bastepe M, Abu-Zahra H, Frappier D, Burkett K, Carpenter TO, Anderson D, Garabedian M, Sermet I, Fujiwara TM, Morgan K, Tenenhouse HS, Juppner H (2006) SLC34A3 mutations in patients with hereditary hypophosphatemic rickets with hypercalciuria predict a key role for the sodium-phosphate cotransporter NaPi-IIc in maintaining phosphate homeostasis. Am J Hum Genet 78:179 192

58. Proesmans W (2006) Threading through the mizmaze of Bartter syndrome. Pediatr Nephrol 21:896-902

59. Simon DB, Karet FE, Hamdan JM, DiPietro A, Sanjad SA, Lifton RP (1996) Bartter's syndrome, hypokalaemic alkalosis with hypercalciuria, is caused by mutations in the $\mathrm{Na}-\mathrm{K}-2 \mathrm{Cl}$ cotransporter NKCC2. Nat Genet 13:183-188

60. Simon DB, Karet FE, Rodriguez-Soriano J, Hamdan JH, DiPietro A, Trachtman H, Sanjad SA, Lifton RP (1996) Genetic heterogeneity of Bartter's syndrome revealed by mutations in the K+ channel, ROMK. Nat Genet 14:152-156

61. Simon DB, Bindra RS, Mansfield TA, Nelson-Williams C, Mendonca E, Stone R, Schurman S, Nayir A, Alpay H, Bakkaloglu A, Rodriguez-Soriano J, Morales JM, Sanjad SA, Taylor CM, Pilz D, Brem A, Trachtman H, Griswold W, Richard GA, John E, Lifton RP (1997) Mutations in the chloride channel gene, CLCNKB, cause Bartter's syndrome type III. Nat Genet 17:171-178

62. Birkenhager R, Otto E, Schurmann MJ, Vollmer M, Ruf EM, Maier-Lutz I, Beekmann F, Fekete A, Omran H, Feldmann D, Milford DV, Jeck N, Konrad M, Landau D, Knoers NV, Antignac C, Sudbrak R, Kispert A, Hildebrandt F (2001) Mutation of BSND causes Bartter syndrome with sensorineural deafness and kidney failure. Nat Genet 29:310-314

63. Hebert SC, Brown EM, Harris HW (1997) Role of the Ca(2+)sensing receptor in divalent mineral ion homeostasis. J Exp Biol 200:295-302

64. Thakker RV (1998) Disorders of the calcium-sensing receptor. Biochim Biophys Acta 1448:166-170

65. Brown EM, MacLeod RJ (2001) Extracellular calcium sensing and extracellular calcium signaling. Physiol Rev 81:239-297

66. Riccardi D, Hall AE, Chattopadhyay N, Xu JZ, Brown EM, Hebert SC (1998) Localization of the extracellular $\mathrm{Ca} 2+$ / polyvalent cation-sensing protein in rat kidney. Am J Physiol 274:F611-F622

67. Riccardi D, Park J, Lee WS, Gamba G, Brown EM, Hebert SC (1995) Cloning and functional expression of a rat kidney extracellular calcium/polyvalent cation-sensing receptor. Proc Natl Acad Sci USA 92:131-135 
68. Pearce SH, Williamson C, Kifor O, Bai M, Coulthard MG, Davies M, Lewis-Barned N, McCredie D, Powell H, KendallTaylor P, Brown EM, Thakker RV (1996) A familial syndrome of hypocalcemia with hypercalciuria due to mutations in the calcium-sensing receptor. N Engl J Med 335:1115-1122

69. Pollak MR, Brown EM, Estep HL, McLaine PN, Kifor O, Park J, Hebert SC, Seidman CE, Seidman JG (1994) Autosomal dominant hypocalcaemia caused by a $\mathrm{Ca}(2+)$-sensing receptor gene mutation. Nat Genet 8:303-307

70. Okazaki R, Chikatsu N, Nakatsu M, Takeuchi Y, Ajima M, Miki J, Fujita T, Arai M, Totsuka Y, Tanaka K, Fukumoto S (1999) A novel activating mutation in calcium-sensing receptor gene associated with a family of autosomal dominant hypocalcemia. J Clin Endocrinol Metab 84:363-366

71. Pattaragarn A, Fox J, Alon US (2004) Effect of the calcimimetic NPS R-467 on furosemide-induced nephrocalcinosis in the young rat. Kidney Int 65:1684-1689

72. Michelis MF, Drash AL, Linarelli LG, De Rubertis FR, Davis BB (1972) Decreased bicarbonate threshold and renal magnesium wasting in a sibship with distal renal tubular acidosis. Evaluation of the pathophysiological role of parathyroid hormone. Metabolism 21:905-920

73. Weber S, Hoffmann K, Jeck N, Saar K, Boeswald M, KuwertzBroeking E, Meij II, Knoers NV, Cochat P, Sulakova T, Bonzel KE, Soergel M, Manz F, Schaerer K, Seyberth HW, Reis A, Konrad M (2000) Familial hypomagnesaemia with hypercalciuria and nephrocalcinosis maps to chromosome $3 \mathrm{q} 27$ and is associated with mutations in the PCLN-1 gene. Eur J Hum Genet 8:414-422

74. Weber S, Schneider L, Peters M, Misselwitz J, Ronnefarth G, Boswald M, Bonzel KE, Seeman T, Sulakova T, KuwertzBroking E, Gregoric A, Palcoux JB, Tasic V, Manz F, Scharer K, Seyberth HW, Konrad M (2001) Novel paracellin-1 mutations in 25 families with familial hypomagnesemia with hypercalciuria and nephrocalcinosis. J Am Soc Nephrol 12:1872-1881

75. Simon DB, Lu Y, Choate KA, Velazquez H, Al-Sabban E, Praga M, Casari G, Bettinelli A, Colussi G, Rodriguez-Soriano J, McCredie D, Milford D, Sanjad S, Lifton RP (1999) Paracellin1 , a renal tight junction protein required for paracellular $\mathrm{Mg} 2+$ resorption. Science 285:103-106

76. Praga M, Vara J, Gonzalez-Parra E, Andres A, Alamo C, Araque A, Ortiz A, Rodicio JL (1995) Familial hypomagnesemia with hypercalciuria and nephrocalcinosis. Kidney Int 47:1419-1425

77. Nicholson JC, Jones CL, Powell HR, Walker RG, McCredie DA (1995) Familial hypomagnesaemia-hypercalciuria leading to end-stage renal failure. Pediatr Nephrol 9:74-76

78. Torralbo A, Pina E, Portoles J, Sanchez-Fructuoso A, Barrientos A (1995) Renal magnesium wasting with hypercalciuria, nephrocalcinosis and ocular disorders. Nephron 69:472-475

79. Blanchard A, Jeunemaitre X, Coudol P, Dechaux M, Froissart M, May A, Demontis R, Fournier A, Paillard M, Houillier P (2001) Paracellin-1 is critical for magnesium and calcium reabsorption in the human thick ascending limb of Henle. Kidney Int 59:22062215

80. Mayan H, Munter G, Shaharabany M, Mouallem M, Pauzner R, Holtzman EJ, Farfel Z (2004) Hypercalciuria in familial hyperkalemia and hypertension accompanies hyperkalemia and precedes hypertension: description of a large family with the Q565E WNK4 mutation. J Clin Endocrinol Metab 89:4025-4030

81. Jiang Y, Ferguson WB, Peng JB (2007) WNK4 enhances TRPV5-mediated calcium transport: potential role in hypercalciuria of familial hyperkalemic hypertension caused by gene mutation of WNK4. Am J Physiol Renal Physiol 292: F545-F554

82. Jarolim P, Shayakul C, Prabakaran D, Jiang L, Stuart-Tilley A, Rubin HL, Simova S, Zavadil J, Herrin JT, Brouillette J, Somers
MJ, Seemanova E, Brugnara C, Guay-Woodford LM, Alper SL (1998) Autosomal dominant distal renal tubular acidosis is associated in three families with heterozygosity for the R589H mutation in the AE1 (band 3) Cl-/HCO3- exchanger. J Biol Chem 273:6380-6388

83. Devonald MA, Smith AN, Poon JP, Ihrke G, Karet FE (2003) Non-polarized targeting of AE1 causes autosomal dominant distal renal tubular acidosis. Nat Genet 33:125-127

84. Karet FE, Finberg KE, Nelson RD, Nayir A, Mocan H, Sanjad SA, Rodriguez-Soriano J, Santos F, Cremers CW, Di Pietro A, Hoffbrand BI, Winiarski J, Bakkaloglu A, Ozen S, Dusunsel R, Goodyer P, Hulton SA, Wu DK, Skvorak AB, Morton CC, Cunningham MJ, Jha V, Lifton RP (1999) Mutations in the gene encoding B1 subunit of $\mathrm{H}+-$ ATPase cause renal tubular acidosis with sensorineural deafness. Nat Genet 21:84-90

85. Ruf R, Rensing C, Topaloglu R, Guay-Woodford L, Klein C, Vollmer M, Otto E, Beekmann F, Haller M, Wiedensohler A, Leumann E, Antignac C, Rizzoni G, Filler G, Brandis M, Weber JL, Hildebrandt F (2003) Confirmation of the ATP6B1 gene as responsible for distal renal tubular acidosis. Pediatr Nephrol 18:105-109

86. Smith AN, Skaug J, Choate KA, Nayir A, Bakkaloglu A, Ozen S, Hulton SA, Sanjad SA, Al-Sabban EA, Lifton RP, Scherer SW, Karet FE (2000) Mutations in ATP6N1B, encoding a new kidney vacuolar proton pump $116-\mathrm{kD}$ subunit, cause recessive distal renal tubular acidosis with preserved hearing. Nat Genet 26:71-75

87. Sly WS, Hewett-Emmett D, Whyte MP, Yu YS, Tashian RE (1983) Carbonic anhydrase II deficiency identified as the primary defect in the autosomal recessive syndrome of osteopetrosis with renal tubular acidosis and cerebral calcification. Proc Natl Acad Sci USA 80:2752-2756

88. Ismail EA, Abul Saad S, Sabry MA (1997) Nephrocalcinosis and urolithiasis in carbonic anhydrase II deficiency syndrome. Eur J Pediatr 156:957-962

89. Pak CY, Kaplan R, Bone H, Townsend J, Waters O (1975) A simple test for the diagnosis of absorptive, resorptive and renal hypercalciuria. N Engl J Med 292:497-500

90. Bataille P, Fardellone P, Ghazali A, Cayrolle G, Hottelart C, Achard JM, Fournier A (1998) Pathophysiology and treatment of idiopathic hypercalciuria. Curr Opin Rheumatol 10:373-388

91. Bataille P, Achard JM, Fournier A, Boudailliez B, Westeel PF, el Esper N, Bergot C, Jans I, Lalau JD, Petit J (1991) Diet, vitamin $\mathrm{D}$ and vertebral mineral density in hypercalciuric calcium stone formers. Kidney Int 39:1193-1205

92. Coe FL, Canterbury JM, Firpo JJ, Reiss E (1973) Evidence for secondary hyperparathyroidism in idiopathic hypercalciuria. J Clin Invest 52:134-142

93. Frick KK, Bushinsky DA (2003) Molecular mechanisms of primary hypercalciuria. J Am Soc Nephrol 14:1082-1095

94. Maierhofer WJ, Lemann J Jr, Gray RW, Cheung HS (1984) Dietary calcium and serum 1,25-(OH)2-vitamin D concentrations as determinants of calcium balance in healthy men. Kidney Int 26:752-759

95. Maierhofer WJ, Gray RW, Cheung HS, Lemann J Jr (1983) Bone resorption stimulated by elevated serum 1,25-(OH)2-vitamin D concentrations in healthy men. Kidney Int 24:555-560

96. Santos F, Smith MJ, Chan JC (1986) Hypercalciuria associated with long-term administration of calcitriol (1,25-dihydroxyvitamin D3). Action of hydrochlorothiazide. Am J Dis Child 140:139-142

97. Kaplan RA, Haussler MR, Deftos LJ, Bone H, Pak CY (1977) The role of 1 alpha, 25-dihydroxyvitamin $\mathrm{D}$ in the mediation of intestinal hyperabsorption of calcium in primary hyperparathyroidism and absorptive hypercalciuria. J Clin Invest 59:756-760

98. Zerwekh JE, Pak CY (1980) Selective effects of thiazide therapy on serum 1 alpha,25-dihydroxyvitamin D and intestinal calcium 
absorption in renal and absorptive hypercalciurias. Metabolism 29:13-17

99. Tenenhouse HS, Gauthier C, Chau H, St-Arnaud R (2004) 1alpha-Hydroxylase gene ablation and $\mathrm{Pi}$ supplementation inhibit renal calcification in mice homozygous for the disrupted Npt2a gene. Am J Physiol Renal Physiol 286:F675-F681

100. Shimada T, Mizutani S, Muto T, Yoneya T, Hino R, Takeda S, Takeuchi Y, Fujita T, Fukumoto S, Yamashita T (2001) Cloning and characterization of FGF23 as a causative factor of tumorinduced osteomalacia. Proc Natl Acad Sci USA 98:6500-6505

101. Rowe PS, Oudet CL, Francis F, Sinding C, Pannetier S, Econs MJ, Strom TM, Meitinger T, Garabedian M, David A, Macher MA, Questiaux E, Popowska E, Pronicka E, Read AP, Mokrzycki A, Glorieux FH, Drezner MK, Hanauer A, Lehrach H, Goulding JN, O'Riordan JL (1997) Distribution of mutations in the PEX gene in families with X-linked hypophosphataemic rickets (HYP). Hum Mol Genet 6:539-549

102. Yao J, Kathpalia P, Bushinsky DA, Favus MJ (1998) Hyperresponsiveness of vitamin $\mathrm{D}$ receptor gene expression to 1,25 dihydroxyvitamin D3 A new characteristic of genetic hypercalciuric stone-forming rats. J Clin Invest 101:2223-2232

103. Li XQ, Tembe V, Horwitz GM, Bushinsky DA, Favus MJ (1993) Increased intestinal vitamin $\mathrm{D}$ receptor in genetic hypercalciuric rats. A cause of intestinal calcium hyperabsorption. J Clin Invest 91:661-667

104. Favus MJ, Karnauskas AJ, Parks JH, Coe FL (2004) Peripheral blood monocyte vitamin D receptor levels are elevated in patients with idiopathic hypercalciuria. J Clin Endocrinol Metab 89:4937-4943

105. Krieger NS, Stathopoulos VM, Bushinsky DA (1996) Increased sensitivity to $1,25(\mathrm{OH}) 2 \mathrm{D} 3$ in bone from genetic hypercalciuric rats. Am J Physiol 271:C130-C135

106. Bushinsky DA, Neumann KJ, Asplin J, Krieger NS (1999) Alendronate decreases urine calcium and supersaturation in genetic hypercalciuric rats. Kidney Int 55:234-243

107. Weisinger JR, Alonzo E, Machado C, Carlini R, Martinis R, PazMartinez V, Bellorin-Font E (1997) Role of bones in the physiopathology of idiopathic hypercalciuria: effect of amino-bisphosphonate alendronate. Medicina (B Aires) 57(Suppl 1): 45-48

108. Ghazali A, Fuentes V, Desaint C, Bataille P, Westeel A, Brazier M, Prin L, Fournier A (1997) Low bone mineral density and peripheral blood monocyte activation profile in calcium stone formers with idiopathic hypercalciuria. J Clin Endocrinol Metab $82: 32-38$

109. Pacifici R, Rothstein M, Rifas L, Lau KH, Baylink DJ, Avioli LV, Hruska K (1990) Increased monocyte interleukin-1 activity and decreased vertebral bone density in patients with fasting idiopathic hypercalciuria. J Clin Endocrinol Metab 71:138-145

110. Coe FL, Favus MJ, Crockett T, Strauss AL, Parks JH, Porat A, Gantt CL, Sherwood LM (1982) Effects of low-calcium diet on urine calcium excretion, parathyroid function and serum 1,25 $(\mathrm{OH}) 2 \mathrm{D} 3$ levels in patients with idiopathic hypercalciuria and in normal subjects. Am J Med 72:25-32

111. Stapleton FB, Langman CB, Bittle J, Miller LA (1987) Increased serum concentrations of $1,25(\mathrm{OH}) 2$ vitamin $\mathrm{D}$ in children with fasting hypercalciuria. J Pediatr 110:234-237

112. Stapleton FB, Jones DP, Miller LA (1989) Evaluation of bone metabolism in children with hypercalciuria. Semin Nephrol 9:75-78

113. Lein JW, Keane PM (1983) Limitations of the oral calcium loading test in the management of the recurrent calcareous renal stone former. Am J Kidney Dis 3:76-79

114. Aladjem M, Barr J, Lahat E, Bistritzer T (1996) Renal and absorptive hypercalciuria: a metabolic disturbance with varying and interchanging modes of expression. Pediatrics 97:216-219

115. Lauderdale DS, Thisted RA, Wen M, Favus MJ (2001) Bone mineral density and fracture among prevalent kidney stone cases in the Third National Health and Nutrition Examination Survey. J Bone Miner Res 16:1893-1898

116. Asplin JR, Donahue S, Kinder J, Coe FL (2006) Urine calcium excretion predicts bone loss in idiopathic hypercalciuria. Kidney Int 70:1463-1467

117. Vezzoli G, Rubinacci A, Bianchin C, Arcidiacono T, Giambona S, Mignogna G, Fochesato E, Terranegra A, Cusi D, Soldati L (2003) Intestinal calcium absorption is associated with bone mass in stone-forming women with idiopathic hypercalciuria. Am J Kidney Dis 42:1177-1183

118. Pietschmann F, Breslau NA, Pak CY (1992) Reduced vertebral bone density in hypercalciuric nephrolithiasis. J Bone Miner Res 7:1383-1388

119. Jaeger P, Lippuner K, Casez JP, Hess B, Ackermann D, Hug C (1994) Low bone mass in idiopathic renal stone formers: magnitude and significance. J Bone Miner Res 9:1525-1532

120. Barkin J, Wilson DR, Manuel MA, Bayley A, Murray T, Harrison J (1985) Bone mineral content in idiopathic calcium nephrolithiasis. Miner Electrolyte Metab 11:19-24

121. Borghi L, Meschi T, Guerra A, Maninetti L, Pedrazzoni M, Marcato A, Vescovi P, Novarini A (1991) Vertebral mineral content in diet-dependent and diet-independent hypercalciuria. J Urol 146:1334-1338

122. Lawoyin S, Sismilich S, Browne R, Pak CY (1979) Bone mineral content in patients with calcium urolithiasis. Metabolism 28:1250-1254

123. Lindergard B, Colleen S, Mansson W, Rademark C, Rogland B (1983) Calcium-loading test and bone disease in patients with urolithiasis. Proc Eur Dial Transplant Assoc 20:460-465

124. Penido MG, Lima EM, Marino VS, Tupinamba AL, Franca A, Souto MF (2003) Bone alterations in children with idiopathic hypercalciuria at the time of diagnosis. Pediatr Nephrol 18:133-139

125. Penido MG, Lima EM, Souto MF, Marino VS, Tupinamba AL, Franca A (2006) Hypocitraturia: a risk factor for reduced bone mineral density in idiopathic hypercalciuria? Pediatr Nephrol 21:74-78

126. Garcia-Nieto V, Ferrandez C, Monge M, de Sequera M, Rodrigo MD (1997) Bone mineral density in pediatric patients with idiopathic hypercalciuria. Pediatr Nephrol 11:578-583

127. Freundlich M, Alonzo E, Bellorin-Font E, Weisinger JR (2002) Reduced bone mass in children with idiopathic hypercalciuria and in their asymptomatic mothers. Nephrol Dial Transplant 17:1396-1401

128. Elliott P, Dyer A, Stamler R (1989) The INTERSALT study: results for 24 hour sodium and potassium, by age and sex. INTERSALT Co-operative Research Group. J Hum Hypertens 3:323-330

129. Nordin BE, Need AG, Morris HA, Horowitz M (1993) The nature and significance of the relationship between urinary sodium and urinary calcium in women. J Nutr 123:1615-1622

130. Sakhaee K, Harvey JA, Padalino PK, Whitson P, Pak CY (1993) The potential role of salt abuse on the risk for kidney stone formation. J Urol 150:310-312

131. Breslau NA, McGuire JL, Zerwekh JE, Pak CY (1982) The role of dietary sodium on renal excretion and intestinal absorption of calcium and on vitamin D metabolism. J Clin Endocrinol Metab 55:369-373

132. Lemann J Jr, Relman AS (1959) The relation of sulfur metabolism to acid-base balance and electrolyte excretion: the effects of DLmethionine in normal man. J Clin Invest 38:2215-2223

133. Lemann J Jr (1999) Relationship between urinary calcium and net acid excretion as determined by dietary protein and potassium: a review. Nephron 81(Suppl 1):18-25

134. Wasserstein AG, Stolley PD, Soper KA, Goldfarb S, Maislin G, Agus Z (1987) Case-control study of risk factors for idiopathic calcium nephrolithiasis. Miner Electrolyte Metab 13:85-95 
135. Lemann J Jr, Maierhofer WJ, Adams ND, Gray RW (1982) Increased serum 1,25-(OH)2-vitamin D concentrations fail to affect serum or urine phosphate in humans. Adv Exp Med Biol 151:375383

136. Srivastava T, Alon US (2005) Urolithiasis in adolescent children. Adolesc Med Clin 16:87-109

137. Alon U, Warady BA, Hellerstein S (1990) Hypercalciuria in the frequency-dysuria syndrome of childhood. J Pediatr 116:103-105

138. Stapleton FB, Roy S 3rd, Noe HN, Jerkins G (1984) Hypercalciuria in children with hematuria. N Engl J Med 310:1345-1348
139. Butani L, Kalia A (2004) Idiopathic hypercalciuria in childrenhow valid are the existing diagnostic criteria? Pediatr Nephrol 19:577-582

140. Costanzo LS, Windhager EE (1978) Calcium and sodium transport by the distal convoluted tubule of the rat. Am J Physiol 235:F492-F506

141. Jang HR, Lee JW, Heo NJ, Lee JH, Oh YK, Na KY, Joo KW, Han JS (2006) Effects of thiazide on the expression of transient receptor potential vanilloid 5 and calbindin- $\mathrm{D}_{28 \mathrm{~K}}$ in a hypercalciuria rat model. J Am Soc Nephrol 17:355 A 